\title{
THE TENANT AS GUARANTOR: ALBERTA FINANCIAL CONSULTANTS LTD. v. CUTHBERT
}

\author{
WILLIAM A.C. ROWE
}

A recent case as yet unreported, dealing with the assignment of a leasehold interest has a startling and even frightening result for those acting on behalf of landlords. On the basis of the fact situation in Alberta Financial Consultants Ltd. v. Cuthbert, ${ }^{1}$ Veit J. held that the individual defendants, the original lessees who had made an assignment to the corporate defendant, were guarantors of the liability of the corporate defendant to the landlord and were not principally liable. Since the Guarantees Acknowledgement Act R.S.A. 1980 c. G-12 had not been complied with, the landlords were unsuccessful in their action to recover unpaid rent from the individual defendants.

Before seeing how this conclusion was reached and whether it is justifiable, a brief overview of the general law in this area is in order.

\section{LIABILITY OF TENANT TO LANDLORD}

Between a landlord and tenant there is privity of contract by virtue of the agreement between them. There is also privity of estate by virtue of the landlord's granting of the leasehold estate to the tenant. An assignment by the tenant of his leasehold interest destroys the privity of estate as he no longer has any interest in the land, but does not affect the privity of contract. The tenant is still bound by the covenants in the lease contract. After assignment, the tenant may not be sued in debt, but the landlord may recover in an action on the covenant to pay contained in the lease. $^{2}$

\section{LIABILITY OF ASSIGNEE TO LANDLORD}

There is no privity of contract between the landlord and an assignee because the assignee is not a party to the original lease, but there will be privity of estate. ${ }^{3}$ By virtue of the doctrine of privity of estate, the assignee is liable to the landlord for performance of all covenants in the lease that run with the land. Once the assignee has made a further assignment of the lease, the privity of estate is destroyed and, since there never was any privity of contract, the first assignee is not liable to the landlord for any liability occurring after the further assignment.

This state of affairs is an unhappy one for landlords. It has been held that the assignee could assign the lease to an entity with no assets for the express purpose of ridding himself of any further liability to the landlord. ${ }^{4}$

- Barrister \& Solicitor with Schwab, Grape \& Rowe, Edmonton.

1. Alberta Queen's Bench Action No. 8103-32351, April 27, 1984.

2. Barnardv. Goodscall(1612) 79 E.R. 264; Auriolv. Mills(1790) 100 E.R. 912; McCrohanv. Edwards [1927] 1 W.W.R. 9 (Alta. S.C.); Williäms \& Rhodes, Canadian Law of Landlord and Tenant (5th ed.) 15-28, 15-29; 27 Halsbury's (4th ed.) 301.

3. There are certain exceptions cited in Williams \& Rhodes, op. cit. 15-16, 15-27.

4. Hopkinson v. Lovering (1883) 11 Q.B.D. 92 as cited in Williams \& Rhodes op. cit. 15-28. 
The remedy for such a situation is for the assignee to covenant directly with the landlord to pay the rent and observe all other covenants of the lease for the remainder of the term. ${ }^{5}$ The normal procedure is for the landlord, tenant and assignee to enter into an agreement whereby the tenant assigns, and the assignee covenants with the landlord to carry out the terms of the lease. ${ }^{6}$ It has also been held that if the assignee enters into such a covenant with the tenant and the tenant assigns the benefit of the covenant to the landlord that this will be equally effective.?

\section{FACTS AND DECISION}

With this background, let us review the facts of the case. The plaintiffs were landlords suing the individual defendants in their capacity as original tenants for rent and unpaid costs. The individual defendants had assigned their leasehold interest to the corporate defendant who had subsequently gone bankrupt. The plaintiff had been a party to the assignment agreement, consenting to the assignment on the following conditions:

1. That the Assignor is not released from the full performance and observations of all covenants, agreements, terms, provisos and conditions as contained within the mentioned Lease; and

2. That such consent is not deemed or implied as a consent to subsequent assignment or subletting.

The covenant in the original lease with respect to assignment and subletting contained the following proviso:

... provided, however, any consent by the lessor to a transfer, assignment, subletting or parting with possession shall in no way discharge or release the lessee from the full performance and observation of all the terms, conditions, covenants, agreements and provisos herein contained on the part of the lessee to be performed and/or observed.

It can be seen that not only did the lease provide that an assignment would not discharge the tenant from his liability under the lease, but the assignment reaffirmed this position.

Veit $\mathbf{J}$. relies on the recent case of Warnford Investments Ltd. v. Duckworth ${ }^{8}$ as setting forth the general position of an original lessee, which corresponds to the propositions set out above. She quotes Megarry V.C.'s observation that in certain cases the liability of the original tenant had been described as being that of a surety for the performance of the assignee. She then cites two cases for the proposition that where "a lessee arranged that the landlord should be a party to the contract of assignment, the lessee can be relieved of the ongoing obligation to pay rent'".9

What then follows is the ratio of the case:

In this case, of course, the agreement signed and sealed by the third parties purported specifically to maintain the obligation of the original lessee. What is significant therefore, is not the content of the deed, but the very participation by the lessor in the deed. In law, as can be seen above, there is no need for such an instrument. Yet, the

5. J. Lyons \& Co. Lid. v. Knowles [1943] 1 All E.R. 477 (C.A.).

6. For a precedent of such an agreement see Schapiro, Alan, "Assignments, subletting and other transfers of leasehold interests", published in Commercial Leases, 1983 L.E.S.A. 32.

7. Butler Estates Co. Lid. v. Bean [1942] I K.B. 1 (C.A.).

8. [1979] Ch. D. 127.

9. Montgomeryv. Spence (1863) 23 U.C.Q.B. 39 (Ont. Q.B.); Chancellor v. Poole (1781) 99 E.R. 488. 
lessor and original lessee always dealt with one another in a most formal way as the 27 page original lease attests. The participation of the original lessor in a deed pursuant to which the original privity of the contract is extended to the assignee can only be $10 \mathrm{~cm}$ phasize the "surety" aspect of the original lease. This deed merges with the original lease. The assignment, therefore, comes within the statutory definition of "guarantee" found in s. I(a) of the Guarantees Acknowledgement Act, R.S.A. 1980, c. G-12, which provisions were also in existence at the time of the signature of the assignment.

There has been no compliance with the requirements of that Act. Therefore, the "guarantee" contained in the assignment cannot be enforced as against the lessees who have obtained a statutory immunity. The merger of the two obligations prevents reliance by the plaintiff on the original lease.

The argument seems to be as follows:

1. The landlord was joined as a third party in the assignment.

2. It was not necessary to do so for the purpose of making the lessee liable to the landlord.

3. Because the parties dealt with each other on a formal basis, there must have been a reason for the landlord to become a party to the assignment.

4. The reason "can only be to emphasize the 'surety' aspect of the original lease".

5. The assignment is therefore a guarantee.

6. The original lease merges with the assignment.

7. Therefore, the landlord cannot rely on the covenant to pay in the lease but only what is contained in the assignment.

8. There was no compliance with the Guarantees Acknowledgement Act in the execution of the assignment.

9. Therefore the landlord's claim against the individual defendants fails.

\section{NO REASON TO BE PARTY TO ASSIGNMENT}

As set out earlier in the discussion of the assignee's liability to the landlord, there is a very good reason for the landlord to be a party to the assignment: To require the assignee to covenant with the landlord to carry out all the terms of the lease. This protects the landlord against future assignments to insolvent assignees. At the same time that the landlord is extracting this covenant from the assignee, it has hitherto been considered good and cautious practice to reiterate the tenant's continuing liability to the landlord notwithstanding that the landlord now has someone else to look to for the rent. This would avoid any argument on the part of the tenant that there has been a novation. This point was briefly mentioned by Master Funduk in Athan Holdings Ltd. v. Merchant Holdings Ltd. ${ }^{10}$

It was argued in the case of $J$. Lyons \& Co.v. Knowles " that

... [W] hen property which carries with it obligations to a third party is transferred from $A$ to $B$, then, if the third party assents to the transfer in such circumstances that the transferee becomes direcily liable to the third party under obligations precisely the same as those of the transferor, the necessary inference is that the third party accepts the obligations of the transferee in substitution for those of the transferor, who is accordingly discharged.

10. (1982) 40 A.R. 199 at 204.

11. [1942] 2 All E.R. 393 (K.B.) at 395. 
This was a case where a landlord was attempting to enforce a covenant to pay against an assignee who had made a further assignment. In the assignment agreement, the assignee had given a covenant to the landlord to pay the rent and observe the terms of the lease. The subsequent assignee gave an identical covenant to the landlord in the subsequent assignment agreement. The first assignee argued that the doctrine of novation as stated above applied so that he would not be liable after the subsequent assignment. The court held that if such a covenant had not been granted, by virtue of the doctrine of privity of estate, the assignee would be liable to pay rent and perform all other covenants that ran with the land only during the time that such privity existed. The purpose for the direct covenant was to bind the assignee for the balance of the term of the lease. Therefore there was no animus novandi and the assignee was liable.

This decision was confirmed in the English Court of Appeal, ${ }^{12}$ where Lord Greene explained the business sense of such a transaction as follows:

When the covenant with the appellant was taken the original lessee, of course, remained liable on his covenant notwithstanding the assignment, but the lease had many years to run. He might die, he might disappear, and so forth and it would have been of importance to the lessors in those circumstances to have somebody standing in his shoes for the residue of the lease in relation to the whole of the term. When the appellant assigned, his assignee again, although no doubt responsible when the original assignment was taken, might become insolvent, and there would be no remedy of any use against it. In circumstances like that it is a matter of simple business to see how important it is for the lessor, if he is fortunate enough to be able to obtain that term when he bargains with his lessee, to have the full benefit of it.

Although this was a case involving an assignee and not an original tenant, the defendant's argument could apply equally to the position of the original tenant.

It is submitted that there was a very good reason for the landlord to be a party to the assignment and also a very good reason for him to reaffirm the original tenant's liability.

\section{LESSEE AS SURETY}

The exact statement of Megarry V.C., cited in this case with respect to the tenant being a surety is as follows: ${ }^{13}$

These are authorities, not explored in the argument before me, for describing the liability of an original lessee after the lease has been assigned as being that of a surety for the performance of the obligations of the lease by the assignee in whom the lease is vested: see, for example, Wolveridge v. Steward (1883) 1 Cr. \& M. 644, 660, and Moule v. Garrett (1870) L.R. 5 Ex. 132, 138; affirmed (1872) L.R. 7 Ex. 101. At first blush, such language might be thought to give some encouragement to the defendants. If the lessee is a mere surety for the rent, would that not bring the defendants within the cover of Stacey v. Hill ? However, I think it is important to consider such statements in their context, and not to read too much into them. As between the lessee and the assignee, such statements reflect the fact that the assignee takes the lease subject to its burdens, and he is under a duty to discharge them. His is the primary duty, and if he fails in his duty and the lessee has to pay, the lessee, like a surety, has the right to be reimbursed by the assignee. That is the position as between the lessee and the assignee which was being considered in the cases. But as between the lessee and the lessor, the position is quite different. The assignment of the lease does nothing to disturb the direct liability of the

12. Supran. 5 at 479.

13. Supran. 8 at $137-138$. 
lessee to the lessor under the lease for the whole of the term. The assignment does not, in my judgment, prevent the lessee from remaining directly and primarily liable to the lessor, or reduce him to being a mere surety towards the lessor for the discharge of the obligations of the lease by the assignee.

The last three sentences of this paragraph clearly indicate that as between the landlord and the tenant, the tenant is not a surety. Megarry V.C. goes on in the next paragraph in his judgment to indicate how a tenant is different from a guarantor in that at no time is a guarantor ever solely liable to the creditor in the way that a tenant is, prior to an assignment.

This issue involved in the Warnford case was whether or not an original lessee was liable to the landlord after there had been an assignment to a limited company which had gone into liquidation and the liquidator had disclaimed the lease. The court held this to be analogous to a situation in which an assignee had gone bankrupt and a trustee had disclaimed the lease. The defendants argued that the position of the original tenant was equivalent to that of a surety. Since the law was that a surety of a tenant was discharged from future liability once the tenant's trustee in bankruptcy disclaimed the lease, the original tenant should similarly be discharged in this situation. That law was determined in the case of Stacey v. Hill. ${ }^{14}$ In Canada the position of the guarantor is not as clear and depends on the wording of the guarantee. ${ }^{15}$

Megarry V.C., distinguished between the position of a guarantor of a lease and the original tenant of an assigned lease. The ratio of the decision in Stacey v. Hill was that the disclaimer puts the lease to an end as between the landlord and tenant and since no rent can be due under it after it has ended, there is nothing for which the guarantor can be liable. A disclaimer of an assignee's interest in a lease, however, does not destroy the term. Megarry V.C., describes the position of the original tenant as follows: 16

The original lessee is a person who, as principal, undertook towards the lessor the obligations of the lease for the whole term; and there is nothing in the process of assignment which replaced this liability by the mere collateral liability of a surety who must pay the rent only if the assignee does not.

The conclusion one must reach from this case is that absent something "in the process of assignment" an original tenant is not merely a surety of the assignee's liability to the landlord, but is a primary debtor. It is submitted that it is incorrect to find that "something" in a clause in the assignment reaffirming the original tenant's liability to the landlord, as was done in the case under consideration.

In the Alberta Financial Consultants Ltd. case, Veit J. found it significant that the landlord had been a party to the assignment. It is interesting to note that the proposition, advanced in the cases noted by Megarry V.C., that a tenant is a guarantor of the liabilities of the assignee does not depend in any way upon the landlord being a party to any assignment. If such a proposition were good law, then by virtue of the noncompliance

14. [1901] 1 K.B. 660 (C.A.).

15. Targa Holdings Ltd. v. Whyte, Walkenden and Morris [1974] 3 W.W.R. 632 (Alta. C.A.); Olivierv. Solloway Mills \& Company Limited(1930) 11 C.B.R. 356.

16. Supran. 8 at 138. 
with the Guarantees Acknowledgement Act coupled with Veit J.'s decision on merger, any assignment of a lease made in Alberta would free the original tenant from further liability to the landlord whether the original tenant was a party to it or not.

\section{LANDLORD AS PARTY TO THE ASSIGNMENT}

Veit J. cites the cases of Chancellor v. Poole ${ }^{17}$ and Montgomery v. Spence ${ }^{18}$ as authority for the proposition that the original tenant can be relieved of the ongoing obligation to pay rent where he arranges for the landlord to be a party to the assignment. It makes sense that this could be the case where the landlord has, by an express term in the assignment, relieved the original tenant of his obligation. It cannot be the case that simply by virtue of being a party to the assignment, without more, the landlord is deemed to relieve the original tenant of his obligation. ${ }^{19}$

In any event, neither of the cases cited are authorities for this proposition. In Chancellor v. Poole, the plaintiff was a landlord claiming against an assignee for rent due after that assignee had made a further assignment. The plaintiff had been a party to the original assignment agreement but the court held there was nothing in the assignment amounting to a covenant by the defendant to be liable for rent for the entire term.

In Montgomery v. Spence, the defendant tenant had alleged that the plaintiff landlord had agreed to discharge him from the covenants in the lease in the assignment agreement. The plaintiff was granted judgment because there was no evidence that there had been an assignment by deed to which the plaintiff was a party, just an oral agreement. Even if there was an assignment, it was held that the landlord could sue on the covenant although he could not bring an action in debt. No agreement to discharge the original tenant was established nor was it discussed by the court.

\section{MERGER}

One of the most critical aspects of this decision is the conclusion by Veit $\mathrm{J}$. that the assignment "merges with the original lease", and that "the merger of the two obligations prevents reliance by the plaintiff on the original lease". No explanation of or rationale for these conclusions is given.

"Merger" is a very versatile term in legal parlance. At least three different uses of the term spring to mind. When judgment has been recovered in an action, the original cause of action is said to have "merged" in the judgment. Similarly, when a creditor takes a security of a higher nature than he already has, his remedies on the minor security are "merged" by operation of law in the higher remedy. ${ }^{20}$

When the holder of a lesser estate in land acquires the fee simple, as when a lessee acquires the freehold, there is a "merger" of the lease in the

17. (1781) 99 E.R. 488.

18. (1863) 23 U.C.Q.B. 39 (Ont. C.A.).

19. See discussion of J. Lyons \& Co.v. Knowles, supra n. 5.

20. 9 Halsbury's (4th Ed.) 416. 
fee, unless there is a contrary intention. ${ }^{21}$ This can also happen when a mortgagee acquires the equity of redemption.

The term is also used to describe the situation in which parties make an executory contract which is to be carried out by a deed executed afterwards. The executory contract is said to "merge" in the deed and one is not allowed to look at the contract except to construe the terms of the deed. It is submitted that this is the type of situation Veit $\mathrm{J}$. is describing. It is also submitted that this third doctrine of merger cannot apply to this case or to any case where the "executory contract" is a formal lease and the "deed" is an assignment.

The leading case in this area is Leggott $v$. Barrett. ${ }^{22}$ In that case, the plaintiff and the defendant had been partners. The plaintiff bought out the defendant and the two entered into an agreement whereby the defendant "would retire from the business". The agreement contained a noncompetition covenant. This agreement was followed by a deed of dissolution which contained the same covenant. A short time later the defendant started up business again in a way that did not violate the covenant, but solicited business from the customers of the old firm. The plaintiff sought an injunction preventing the defendant from soliciting business from old customers and from actually dealing with any old customers. The injunction was granted and the defendant appealed that portion of the judgment preventing him from dealing with old customers under any circumstances. The plaintiff had argued that the clause in the original agreement that stated that the defendant was "to retire from the business" implied just that and therefore the defendant should not be allowed even to deal with old customers whether they had been solicited by the defendant or come to him on their own. The court did not agree with this interpretation, but held that even if it had, the clause was not part of the deed. James L.J., stated: ${ }^{23}$

... [I]f parties have made an executory contract which is to be carried out by a deed afterwards executed, the real completed contract between the parties is to be found in the deed, and ... you have no right whatever to look at the contract, although it is recited in the deed, except for the purpose of construing the deed itself. You have no right to look at the contract either for the purpose of enlarging or diminishing or modifying the contract which is to be found in the deed itself.

Brett L.J. adds: ${ }^{24}$

... where there is a preliminary contract in words which is afterwards reduced into writing, or where there is a preliminary contract in writing which is afterwards reduced into a deed, the rights of the parties are governed in the first case entirely by the writing. and in the second case entirely by the deed; and if there be any difference between the words and the written document in the first case, or between the written agreement and the deed in the other case, the rights of the parties are entirely governed by the superior document and by the governing part of that document.

This proposition is most often encountered in contrasts for the sale of land where there is an interim agreement that is followed by a transfer of land or deed.

21. Daymanv. MacDonald (1907) 7 W.L.R. 296 (Sask. S.C.T.D.).

22. (1880) 15 Ch. D. 306 (C.A.).

23. Supran. 22 at 309.

24. Supran. 22 at 311. 
The important point about these statements is that it is clear that the court is discussing a contract in which the parties contemplate a further formal agreement necessary to carry out the terms of that contract. It is a "preliminary" contract, one "which is to be carried out by a deed". This is clearly not the situation with a lease. Certainly, a lease is an executory contract since there are ongoing obligations of both parties, but the rights and obligations of the parties are fully set forth in the lease itself. The fact that there may be an assignment by one or both of the parties is normally contemplated, but it could not possible be said that the assignment was "necessary" to carry out the terms of the contract.

It could not have been the intention of the parties in the Alberta Financial Consultants Ltd. case that the formal lease merge in the assignment. The assignment constantly refers to the terms and provisos of the lease and emphasizes the obligations of both the tenant and the assignee to observe them. Why would this be done if it was contemplated that the force of the lease would be spent upon the execution of the assignment?

That the intention of the parties is of paramount importance is illustrated by the recent decision in Dyform Engineering Ltd. v. Ittup Hollowcore International Ltd. ${ }^{25}$ In that case the defendant had in 1970 granted to the plaintiff a license to manufacture and sell the defendant's invention. This grant included an agreement that the defendant would disclose to the plaintiff all improvements in the invention. In 1973, the defendant assigned his rights in the invention to the plaintiff. Subsequently, the defendant developed and manufactured an improvement on his invention. The plaintiff claimed breach of the 1970 agreement. The defendant argued that the 1970 agreement merged in the 1973 assignment of patent rights and relied on Leggott $\mathrm{v}$. Barrett. The assignment of patent rights had not expressly released the defendant from his obligations under the 1970 agreement. The court held that the contract was not executory and in any event there was no evidence of any intention that the 1973 agreement was to be the only agreement between the parties. McKinnon J., stated:26

\footnotetext{
How can it be said the parties intended the 1970 agreement be merged in the 1973 assignment? The assignment is what it is said to be. No more nor less. It transfers [the defendant's] interest in the invention and applications for patents and patents in the extrusion machine. It is silent on the assignment of any future improvements, which is the very thing acquired by the plaintiffs in the 1970 agreement.

... in taking [the 1973] assignment, there was no expressed or implied provision the plaintiff should give up the rights it acquired under . . . the 1970 agreement. Accordingly, the plaintiffs may exercise those rights during the term of the agreement....
}

\section{CONCLUSION}

It is submitted that the argument in the Alberta Financial Consultants $L t d$. case does not hold up to analysis. The premise that there was no reason for the landlord to be a party to the assignment is incorrect. This premise is relied upon for the conclusion that the landlord was a party only to emphasize the "surety" aspects of the lease. Therefore that conclusion is not correct. In any event, any authority for the conclusion that

25. (1983) 19 B.L.R. 1 (B.C.S.C.).

26. Supran. 25 at 11 and 13 . 
the tenants are guarantors is expressly negated in the Warnford Investments Ltd. case which is authority for exactly the opposite proposition.

Even if that conclusion were correct, it is submitted that the doctrine of merger does not apply to a lease and an assignment. A formal lease is not a "preliminary" contract, nor is it a contract "which is to be carried out" by a further formal agreement. Therefore the landlord may sue the tenant on the covenant to pay in the original lease. The original lease does not merge in the assignment. 